\title{
Customer's View and Experience with Loyalty Programs in the South Bohemia
}

\author{
Jaroslav Stuchlý ${ }^{1}$, Tsolmon Jambal ${ }^{1}$, Lenka Ližbetinová ${ }^{*}$ \\ ${ }^{1}$ Institute of Technology and Business, School of Expertness and Valuation, Okružní 517/10, 37001 \\ České Budějovice, Czech Republic
}

\begin{abstract}
The aim of the article is to determine the attitudes of South Bohemian customers to the loyalty programs. The article is based on the partial output of research focusing on customer loyalty to loyalty programs. The research was conducted in 2018 by a questionnaire survey with 267 respondents. Respondents interviewed were customers who live in the South Bohemian Region. The results presented in the article are based on the part of the questionnaire, where the respondents answered how much they agree with the fourteen claims concerning loyalty programs. Attention is also focused on looking for dependencies of overall evaluation in relation to loyalty programs in terms of identification variables: gender, age, education and the size of the respondent's place of residence. Two-choice statistical tests and the Kruskal-Wallis test are used to determine dependencies. The statistical program R. was used to perform these tests.
\end{abstract}

Key words: loyalty program, customers, customer view, marketing

\section{Introduction}

Loyalty programs are among the means of sales support. Loyalty program can be defined as a marketing tool that serves to enhance the loyalty of existing customers and to gain confidence in future customers $[1,2]$. The goal of loyalty programs is to motivate a customer who has already bought or used the service to become a permanent customer or stay longer with the product [3]. Furthermore, the loyalty program can be seen as an instrument of competitive advantage $[4,5]$. However, it is not possible to use the "loyalty program". Given that most companies already have some type of loyalty program, the benefits and bonuses of loyalty programs have become commonplace. Many customers are a member of several competing loyalty programs at the same time, and their purchasing decisions are subject to those who offer better conditions at the moment. This is most often the case with loyalty programs of retail chains where chains offer almost identical goods and therefore it is not an obstacle for customers to get these goods in a different store [6, 7]. The Loyalty Program serves to maximize the company's turnover or for certain products. The customer should operate at all stages of the purchasing process [8,9]. According to Brych [10], the loyalty program should be particularly comprehensible, playful, creative and should communicate regularly with clients. Zamazalová [11] sees their sense in creating a long-term relationship between the consumer and the company. The study by Waari, Bonuke and Kosgei [12]

*Corresponding author: lizbetinova@mail.vstecb.cz 
confirms a direct relationship between loyalty programs benefits and customer loyalty. Their study was in the context of hotels with three to five stars. Based on their research, they concluded that the customer loyalty effect is enhanced or becomes stronger when customer satisfaction.

The main prerequisite for a good loyalty program is building customer loyalty, and the pay-out structure should be designed to make sure that the longer the customer stays on the program, the higher the return. This approach is particularly long-term, since keeping loyal customers is easier because they are more willing to pay higher prices [13]. Reichheld and Teal [14] claims that lack of loyalty reduces the company's performance by $25-50 \%$. Relationship marketing has two positive effects, namely to strengthen the endurance of customers combined with the acquisition of new ones. The idea is that the longer customers stay with the brand, the better it will be. Revenue per customer will increase, operational costs will decline, the spread of positive messages between people will attract other customers, and loyal consumers are not so price-sensitive. Several factors influence a customer's satisfaction. These include, for example, satisfaction with goods, satisfaction with the operator, satisfaction with the sales environment or satisfaction with the whole business [15]. At present, an important factor is the use of IT resources to simplify the customization of loyalty programs [16-18]. The company can influence all the above mentioned factors, namely by purchasing marketing in the creation of a supply of goods, by ensuring affordable, quality goods in the required assortment, also by arranging on the sales area and the overall atmosphere in the shop [19], but above all by quality services based on staff, which is trained, willing and pleasant [20-23] and also by the company's overall approach to customers [24, 25].

In the Czech Republic, we can find a wide range of loyalty systems that have become one of the tools of customer engagement. Not only large large-scale retail chains use them, but also non-food stores or specialized shops and service providers including entities in transport and logistics chains [26-28]. They differ from each other by their parameters, offered bonuses and the way discounts are provided. However, they have one thing in common - to keep and attract customers and strengthen their loyalty [29, 30]. Tellis [13] sets out four important principles that can ensure that the bonus program achieves its goals and not just the extra cost of the company, namely: focusing on promising customers (loyal or big customers), building loyalty (reward for brand loyalty, the longer the customer stays on the program, the higher the yield), creating a value for the customer (creating a value the customer cannot just buy or buy on the market) and creating a more profitable than a cost centre (in the long run).

\section{Data and methods}

The aim of the article is to determine the attitudes of South Bohemian customers to forms and to set the conditions of the loyalty programs. The article draws on partial outcomes of research focusing on customer attitudes towards loyalty programs with a focus on the young generation. The young generation has a more positive attitude towards IT and loyalty programs and is more flexible in terms of accessing and sharing loyalty programs with each other. Research was conducted in 2018 by a questionnaire survey of 267 respondents. The interviewees were customers who have their permanent residence in the South Bohemian Region. The results presented in the article are based on the part of the questionnaire, where respondents could answer how much they identify with the 14 loyalty program submissions. They presented their attitudes on the Linkert scale from 1 to 5 , where 1 is totally disagree, 2 disagree, 3 neutral, 4 agree and 5 totally agree.

The total number of respondents is 267 and the sample is composed of $43.5 \%$ of men and $56.5 \%$ of women. In the processing of the results, the basic statistical characteristics were used - relative and absolute frequency, weighted arithmetic mean. Attention is also focused 
on looking for dependencies of the overall evaluation of the relation to loyalty programs on the following identification variables: gender, age, education and the size of the size of respondent's municipality. For the overall evaluation variable (EV), we use the sum of the scores of all variants of the claim by individual respondents. In this calculation, it is necessary to negate the positive statement C10 - C11 and shifts 1 to 5 and 2 to 4 . In particular, we will be interested in whether this evaluation variable depends significantly on the identification variables. We will use statistical two-choice tests and the Kruskal-Wallis test. The statistical program $\mathrm{R}$ was used to perform these tests.

\section{Results and Discussion}

The article presents partial research results that focus on the customers' view of the functioning and loyalty program settings. The dependence of their attitude is tested in terms of age, gender, education, and community size. Their attitudes are examined through identifying 14 claims on the Linkert scale from 1 to 5 , where 1 is totally disagree, 2 disagree, 3 neutral, 4 agree and 5 totally agree. Table 1 and Figure 1 present the identification of respondents with claims $\mathrm{C} 01$ to $\mathrm{C} 14$.

Table 1. Customer's view on the claims about working way of loyalty system

\begin{tabular}{|c|c|c|c|c|c|c|c|c|}
\hline \multirow[b]{2}{*}{ ن } & \multirow[b]{2}{*}{ Claim } & \multicolumn{6}{|c|}{ Percentage of respondents } & \multirow[b]{2}{*}{$\sum_{\Sigma}^{\Xi}$} \\
\hline & & 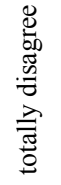 & 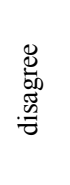 & $\begin{array}{l}\overrightarrow{\widetilde{E}} \\
\stackrel{\Xi}{\Xi}\end{array}$ & $\begin{array}{l}\mathbb{\Xi} \\
\underset{\Xi}{0}\end{array}$ & 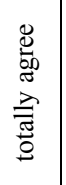 & $\underset{\Xi}{\Xi}$ & \\
\hline $\mathrm{C} 01$ & $\begin{array}{l}\text { Loyalty programs are many and sometimes customers } \\
\text { do not have an overview of which programs are } \\
\text { involved }\end{array}$ & 3.7 & 16.9 & 17.6 & 44.2 & 17.6 & 100 & 3.55 \\
\hline $\mathrm{C} 02$ & $\begin{array}{l}\text { Loyalty programs are so many that customers are no } \\
\text { longer interested in registering }\end{array}$ & 4.1 & 13.9 & 25.1 & 43.4 & 13.5 & 100 & 3.48 \\
\hline $\mathrm{C} 03$ & $\begin{array}{l}\text { Mostly, there is not enough care about members of the } \\
\text { loyalty program }\end{array}$ & 4.5 & 14.6 & 34.1 & 35.2 & 11.6 & 100 & 3.35 \\
\hline $\mathrm{C} 04$ & $\begin{array}{l}\text { Targeting offers to members of loyalty programs is } \\
\text { often inaccurate }\end{array}$ & 3.7 & 22.1 & 33.3 & 34.5 & 6.4 & 100 & 3.18 \\
\hline $\mathrm{C} 05$ & $\begin{array}{l}\text { The awareness of members of the loyalty program } \\
\text { about current and new benefits is not sufficient }\end{array}$ & 6.4 & 23.2 & 30.0 & 33.3 & 7.1 & 100 & 3.12 \\
\hline $\mathrm{C} 06$ & $\begin{array}{l}\text { Loyalty programs are often so complex that it is } \\
\text { unclear under which conditions benefits are gained }\end{array}$ & 5.6 & 25.1 & 21.7 & 38.6 & 9 & 100 & 3.20 \\
\hline $\mathrm{C} 07$ & $\begin{array}{l}\text { Contacting loyalty program members with unintended } \\
\text { offerings is common }\end{array}$ & 6.0 & 22.5 & 32.6 & 31.8 & 7.1 & 100 & 3.12 \\
\hline $\mathrm{C} 08$ & $\begin{array}{l}\text { Frequent problem is the time-limited possibility of } \\
\text { applying the benefit }\end{array}$ & 3.4 & 15.7 & 27.0 & 36.7 & 17.2 & 100 & 3.49 \\
\hline $\mathrm{C} 09$ & $\begin{array}{l}\text { There are frequent technical problems with loyalty } \\
\text { programs (for example, the card cannot identify the } \\
\text { customer - it must be re-registered) }\end{array}$ & 20.2 & 36.0 & 23.2 & 14.2 & 6.4 & 100 & 2.51 \\
\hline $\mathrm{C} 10$ & $\begin{array}{l}\text { I'm not confronted with problems with loyalty } \\
\text { programs }\end{array}$ & 6.4 & 24.3 & 26.2 & 31.8 & 11.2 & 100 & 3.17 \\
\hline $\mathrm{C} 11$ & I like to use loyalty programs & 3.0 & 11.2 & 26.2 & 40.8 & 18.7 & 100 & 3.61 \\
\hline $\mathrm{C} 12$ & $\begin{array}{l}\text { A well-defined loyalty program motivates me to shop } \\
\text { in specific stores }\end{array}$ & 5.2 & 12.0 & 24.7 & 42.3 & 15.7 & 100 & 3.51 \\
\hline $\mathrm{C} 13$ & $\begin{array}{l}\text { The benefits of membership motivate me to make more } \\
\text { frequent purchases }\end{array}$ & 6.4 & 17.2 & 26.2 & 37.8 & 12.4 & 100 & 3.33 \\
\hline $\mathrm{C} 14$ & I am not satisfied with the loyalty programs offered & 8.6 & 34.1 & 35.2 & 16.5 & 5.6 & 100 & 2.76 \\
\hline Total & & 6,2 & 20.6 & 27.4 & 34.4 & 11.4 & 100 & 3.24 \\
\hline
\end{tabular}

Source: Authors. 
From the presented results (Table 1 and Figure 1), most of the customers use the loyalty programs in general (final mark 3.61 - the weighted arithmetic average of the respondents' rating) and the benefits of customer membership motivate for more frequent purchases (up to $60.2 \%$, mark 3.51 ). On the other hand, $61.8 \%$ of customers are arguing that loyalty programs are many and customers sometimes have no insight into which of them are involved. Also, $56.9 \%$ of customers think that loyalty programs are so many that customers are no longer interested in registering for others. They also have a more negative view of the temporary nature of the use of benefits ( $53.9 \%$ it does not, and $27 \%$ to that is neutral). $46.8 \%$ customer agrees with the statement that is usually sufficient care for members of the loyalty program (34.1\% to the set neutral), which creates an area for improvement. On the contrary, customers report that they do not have frequent technical problems $(56.2 \%)$ in the operation of loyalty programs (eg card cannot identify the customer, etc.) and most of them deny that they would not be satisfied with the loyalty programs offered $(22.1 \%$ are not satisfied and $35.2 \%$ state a neutral stance).

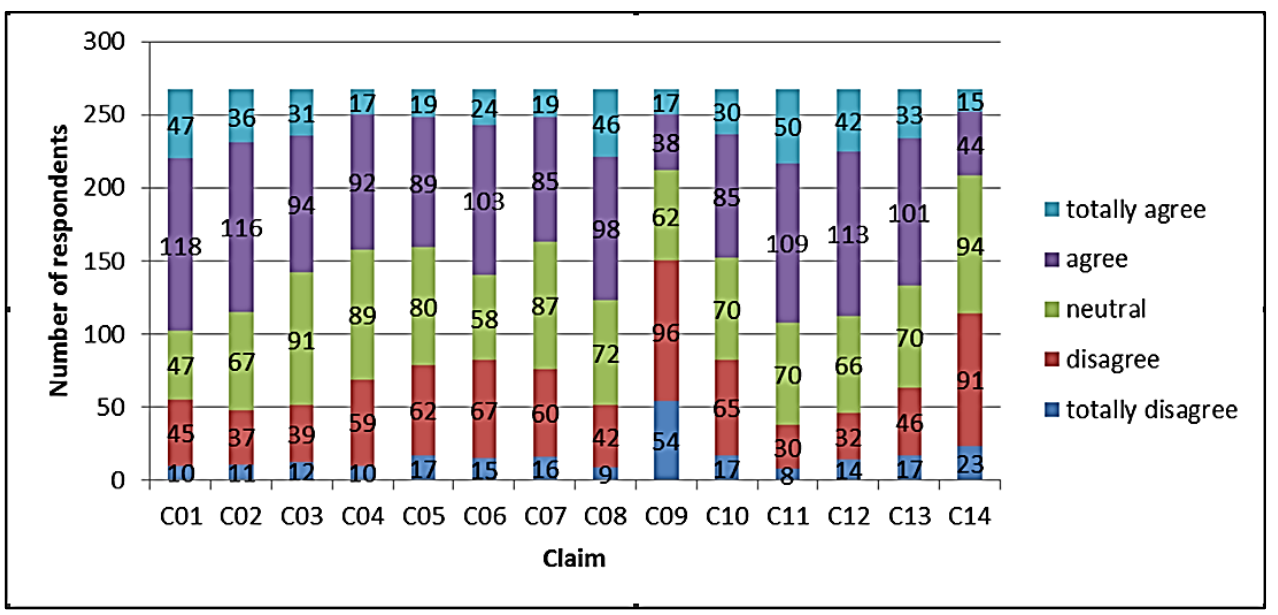

Fig. 1. Frequency distribution for the claims

Source: Authors.

In the next section, the dependence of the overall assessment of attitudes on loyalty programs is tested in relation to the identification variables: gender, age, education and the size of the respondent's residence. The overall evaluation variable (EV) is created as a sum of the scores of all variants of claims by individual respondents. Dependence is tested using statistical two-choice tests and the Kruskal-Wallis test. In Table 2, there are calculated basic numerical characteristics of the EV variable and its course is approximated by the box diagram and the absolute frequency histogram (see Figure 2).

Table 2. Numerical characteristics of EV evaluation

\begin{tabular}{|l|l|l|l|l|l|l|l|l|l|l|l|}
\hline mean & sd & IQR & coef.var. & skewness & kurtosis & min & $25 \%$ qu. & median & $75 \%$ qu. & $\max$ & $n$ \\
\hline 43.81 & 6.26 & 7 & 0.143 & -0.520 & 0.777 & 22 & 41 & 44 & 48 & 62 & 267 \\
\hline
\end{tabular}

Source: Authors. 

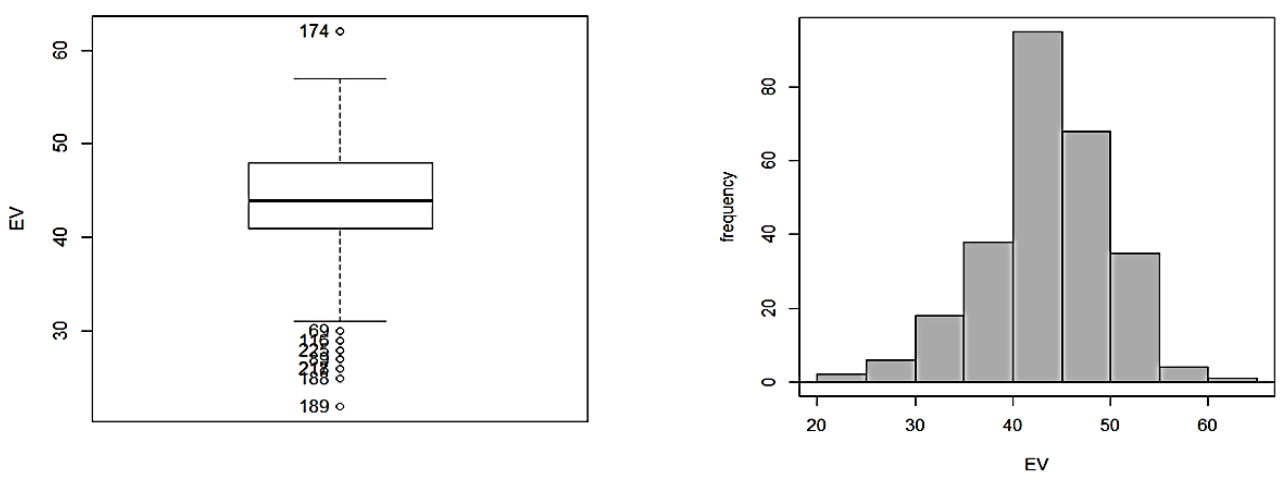

Fig. 2. Distribution of EV evaluation quantity - box diagram and histogram of absolute frequencies Source: Authors.

The normality of data transformation is tested by Shapiro-Wilk's test, with outputs $\mathrm{W}=$ 0.9766 , p-value $=0.000221$. Based on the test result, normality was rejected at $5 \%$ significance level. It is probably caused by a number of outlying values and for this reason, there will be used non-parametric tests. Table 3 presents the conditional numerical characteristics of the EV variable by gender, and Figure 3 illustrates the conditional distributions.

Table 3. Conditional numerical characteristics of EV evaluating gender by gender

\begin{tabular}{|c|c|c|c|c|c|c|c|c|c|c|c|c|}
\hline sex & mean & sd & IQR & coef.var. & skewness & kurtosis & min & $25 \%$ qu. & median & $\begin{array}{c}75 \% \\
\text { qu. }\end{array}$ & max & $\mathrm{n}$ \\
\hline female & 43.91 & 5.78 & 7 & 0.132 & -0.326 & 0.287 & 27 & 41 & 44 & 48 & 57 & 151 \\
\hline male & 43.67 & 6.86 & 8 & 0.157 & -0.651 & 0.953 & 22 & 40 & 44 & 48 & 62 & 116 \\
\hline
\end{tabular}

Source: Authors.

Testing the independence of the EV variable on sex is performed using the Wilcoxon's two-choice test. The values obtained are $\mathrm{W}=8726.5$, $\mathrm{p}$-value $=0.9604$. The fact that $\mathrm{EV}$ is gender-neutral has already been deduced from the Figure 3 and the Table 3.

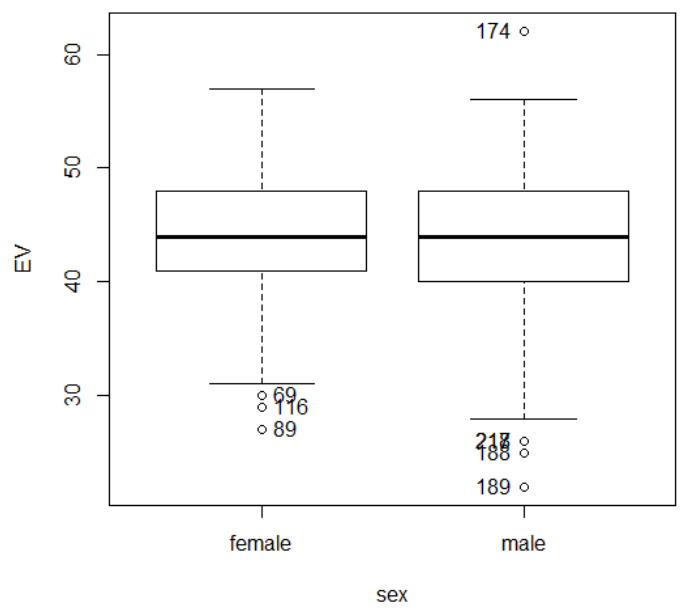

Fig. 3. Conditional distribution of the EV evaluation variable by gender

Source: Authors. 
Also, the test failed to prove this dependence at a 5\% level of significance. Consequently, the dependency test of the respondents is tested. For this purpose, the conditional numerical characteristics and the conditional distribution are presented in Table 4 and in Graph 4.

Table 4. Conditional numerical characteristics of EV evaluation by age

\begin{tabular}{|c|c|c|c|c|c|c|c|c|c|c|c|c|}
\hline age & mean & sd & IQR & coef.var. & skewness & kurtosis & min & $\begin{array}{c}25 \% \\
\text { qu. }\end{array}$ & median & $\begin{array}{c}75 \% \\
\text { qu. }\end{array}$ & max & $\mathrm{n}$ \\
\hline $15-29$ & 42.76 & 6.62 & 8 & 0.155 & -0.800 & 0.705 & 22 & 40 & 43 & 48 & 57 & 123 \\
\hline $30-39$ & 45.78 & 5.77 & 8 & 0.126 & 0.080 & 0.185 & 31 & 42 & 46 & 50 & 62 & 68 \\
\hline $40-49$ & 44.12 & 6.15 & 6.5 & 0.139 & -0.342 & 0.199 & 29 & 41.5 & 44 & 48 & 57 & 51 \\
\hline $50-59$ & 42.67 & 5.20 & 7.75 & 0.122 & 0.267 & -1.039 & 34 & 39 & 41.5 & 46.75 & 51 & 18 \\
\hline $\begin{array}{c}60 \text { and } \\
\text { more }\end{array}$ & 43.86 & 3.18 & 1.5 & 0.073 & -2.159 & 4.846 & 37 & 44 & 45 & 45.5 & 46 & 7 \\
\hline
\end{tabular}

Source: Authors.

The conditional numerical characteristics and the conditional distribution are also presented in Graph 4.

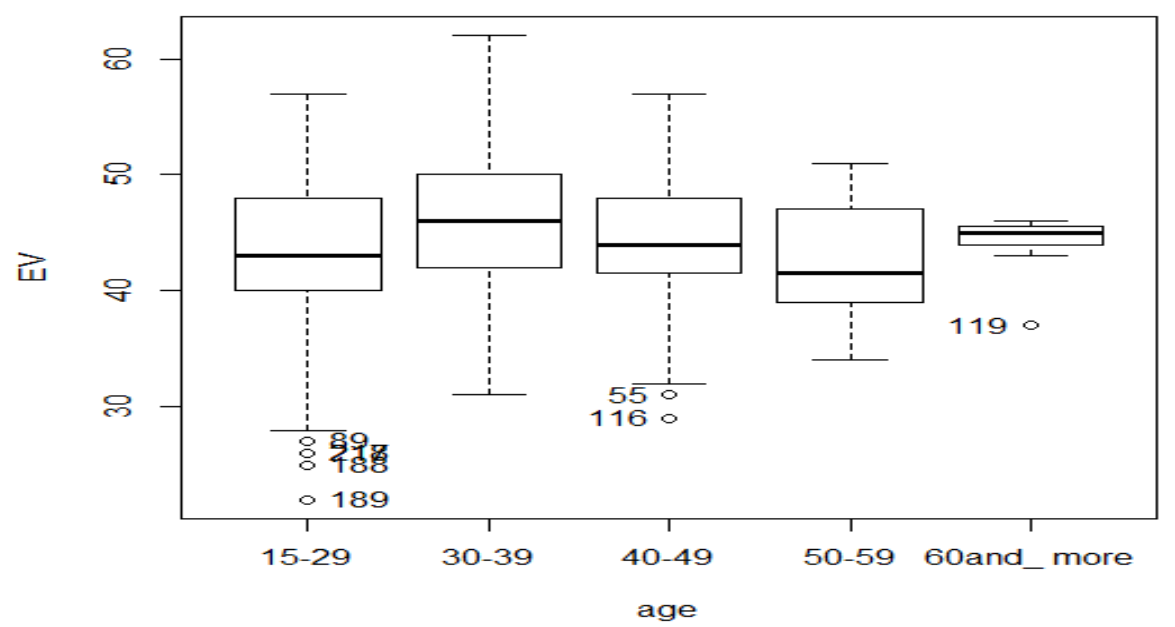

Fig. 4. Conditional distribution of the assessment variable EV by age

Source: Authors.

The Kruskal-Wallis test is used to test the independence of the EV variable for the ages and result is chi-squared $=9.1841, \mathrm{df}=4, \mathrm{p}$-value $=0.05666$. Already from Chart 4 and Table 4 it is foreseeable that EV is age dependent. However, this dependence was not proven by the test at a 5\% level of significance. However, there is confirmed a statistically significant EV dependence from age to $10 \%$ significance level. Another fact examined is dependence on the education of respondents. Conditional numerical characteristics are shown in Table 5. 
Table 5. Conditional numerical characteristics of the EV evaluation variable by education

\begin{tabular}{|l|c|c|r|r|r|r|r|r|r|r|r|r|}
\hline education & mean & sd & IQR & coef.var. & skewness & kurtosis & min & $25 \%$ qu. & median & $75 \%$ qu. & $\max$ & $\mathrm{n}$ \\
\hline university & 43.90 & 7.07 & 7 & 0.161 & -0.589 & 0.458 & 22 & 41 & 44 & 48 & 57 & 73 \\
\hline $\begin{array}{l}\text { upper } \\
\text { secondary }\end{array}$ & 42.15 & 6.89 & 9 & 0.164 & -0.528 & 0.225 & 26 & 37 & 43 & 46 & 55 & 40 \\
\hline $\begin{array}{l}\text { lower } \\
\text { secondary }\end{array}$ & 44.41 & 5.66 & 7.25 & 0.127 & -0.414 & 1.141 & 25 & 41 & 44 & 48.25 & 62 & 144 \\
\hline primary & 41.10 & 4.15 & 1.75 & 0.101 & -1.069 & 1.995 & 32 & 41 & 41.5 & 42.75 & 47 & 10 \\
\hline
\end{tabular}

Source: Authors.

Conditional distribution is shown on Figure 5.

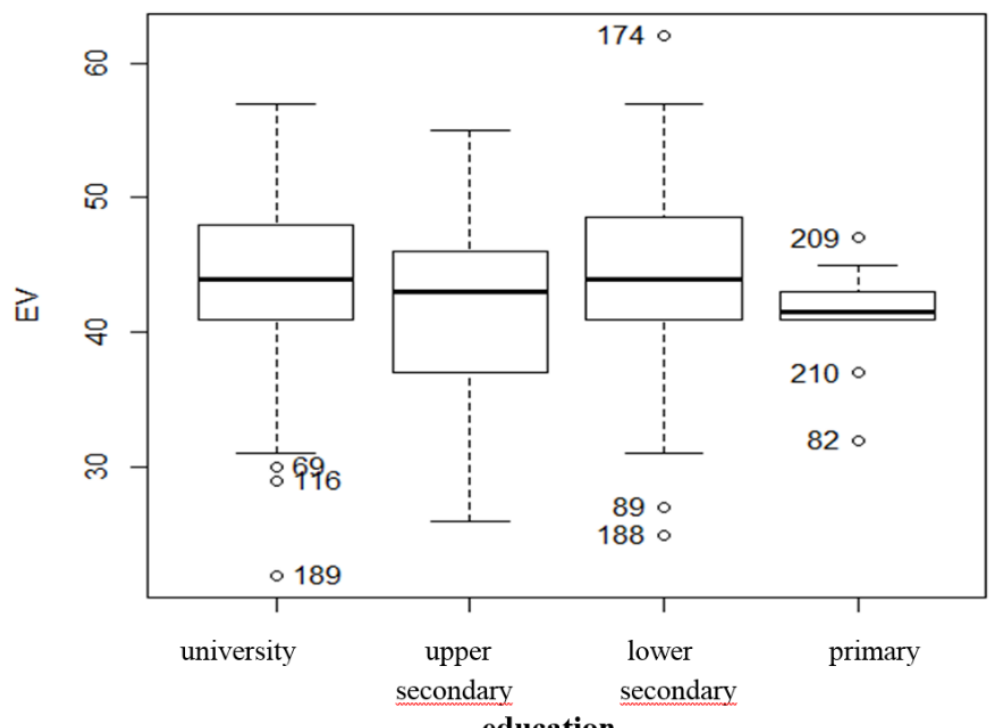

Fig. 5. Conditional distribution of EV evaluation value by education

Source: Authors.

The Kruskal-Wallis test is used to test the independence of the EV variable by education and the result of this test is: chi-squared $=6.1148, \mathrm{df}=3, \mathrm{p}$-value $=0.1062$. There is evidence in Figure 5 and Table 5 that EV depends on education. However, the test did not confirm the significance of the statistical significance to the 5\% significance level. Another examined dependency is the dependence of EV on the size of the respondents' residence (expressed in thousands of inhabitants). Conditional numerical characteristics are shown in Table 6.

Table 6. Conditional numerical characteristics evaluation values EV respondents by size of municipality

\begin{tabular}{|l|r|r|r|r|r|r|r|r|r|r|r|r|}
\hline municipality & mean & sd & IQR & coef.var. & skewness & kurtosis & min & $25 \%$ qu & median & $75 \%$ qu & max & $\mathrm{n}$ \\
\hline$(0 ; 1]$ & 44.06 & 6.86 & 8 & 0.156 & -0.932 & 0.760 & 26 & 4 & 45 & 49 & 56 & 53 \\
\hline$(1 ; 10]$ & 43.24 & 5.79 & 6.25 & 0.134 & -0.243 & 0.204 & 27 & 4 & 43 & 46.25 & 57 & 100 \\
\hline$(10 ; 50]$ & 43.90 & 5.87 & 7 & 0.134 & -0.083 & 1.094 & 31 & 4 & 44 & 48 & 62 & 60 \\
\hline$(50 ; 1200]$ & 44.52 & 6.95 & 9 & 0.156 & -0.888 & 1.666 & 22 & 4 & 44 & 50 & 57 & 54 \\
\hline
\end{tabular}

Source: Authors. 
Conditional distribution is shown on Figure 6.

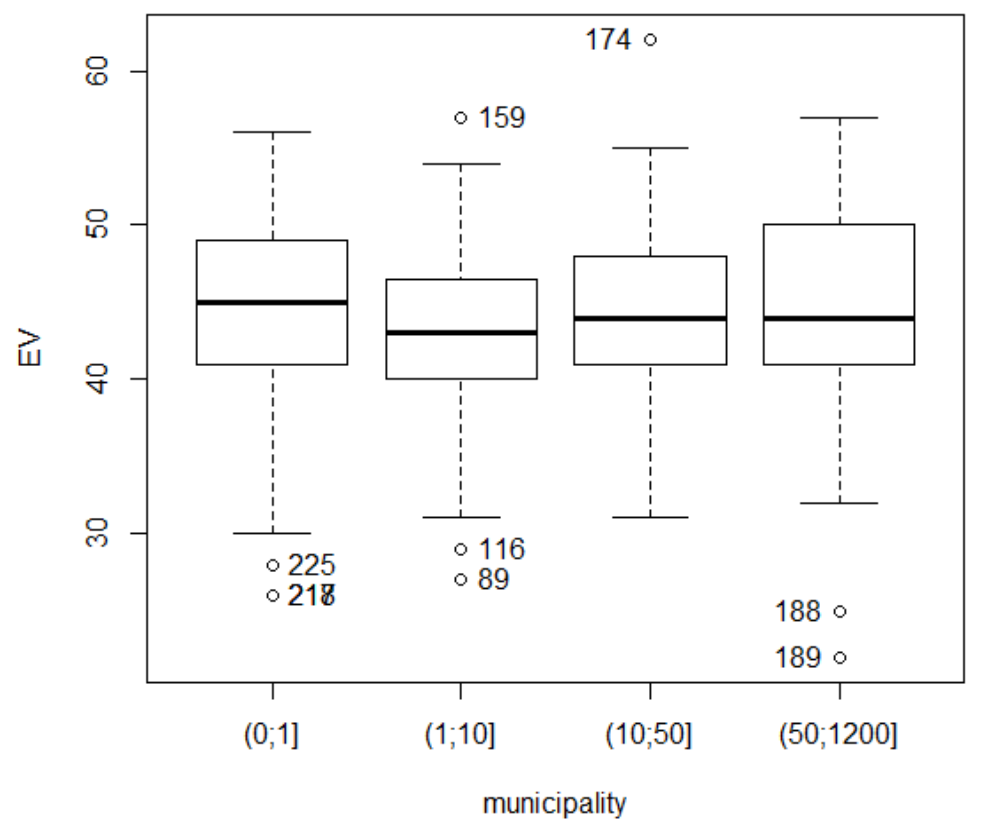

Fig. 6 Conditional distribution of the EV evaluation variable according to the size of the respondents' municipality

Source: Authors.

The test of independence of EV evaluating EV on education is done using the KruskalWallis test. The test provided these outputs: chi-squared $=2.9836, \mathrm{df}=3, \mathrm{p}$-value $=0.3942 \mathrm{~A}$ free view of Figure 5 and Table 5 gives us the assumption that EV does not depend on the size of the residence. This assumption was confirmed by the Kruskal-Wallis test, which confirmed the zero hypothesis and therefore no statistically significant dependence on the $5 \%$ significance level was confirmed.

\section{Conclusion}

The article presents partial research results that focus on customer perceptions of loyalty programs. The dependence of their attitude is tested in terms of age, gender, education, and municipality size. From the processing of the data obtained, it was found that customers mostly enjoy loyalty programs and a well-established loyalty program motivates them to buy more from specific companies. This is confirmed by the control question, which is a negation of satisfaction with loyalty programs, and customers identify with it at least. In the second tent, customers also mention areas where businesses have an area to improve their loyalty program settings. They most sympathize with the belief that loyalty programs are many and customers sometimes do not have an overview of which programs they are involved in. Here is the space to differentiate from other loyalty programs of competition and reduce the demand for its use for customers - friendly setting and ease of use for customers. For customers, the problem area is a time limit for taking advantage of loyalty programs. There is a need to find a compromise point where the program will create a permanent advantage for a trader based on time constraints, while at the same time it will be of interest to the customer so that the time limit is not the fact that the advantage is not paid to him in such a 
short time. Technical and functional loyalty programs do not pose a significant problem for most customers. From the testing of attitudes to loyalty programs in terms of gender, age, education and municipality, there were no statistically significant differences in the significance level of 5\%. Statistically significant dependence EV values was demonstrated only in education at 10\% significance level. No significant dependence on other identification variables has been demonstrated.

When planning and setting loyalty programs with respect to target customers, it is appropriate not only to make effective adjustments, but also to differentiate from loyalty programs of competitors. It follows that if a competitive program exists, then there is a greater pressure on originality and uniqueness. In this way, it is possible to motivate customers to make more frequent purchases in specific stores. An invaluable fact is to consider the time constraint of the benefits offered so that for most of the target customers they are still realistically beneficial and create a sort of compromise between the benefits of one and the other of the relationship.

\section{Acknowledgment}

This paper is an output of the science projects IGS 8110IGS201813, TL02000559 Secure cities for pedestrians and seniors, TL02000017 Intergenerational management to support digitization in construction and TL01000349 Stabilization and development of SMEs in rural areas.

\section{References}

1. M. Tomcik, P. Rosenlacher, Number of advertisements per day and their relevance to consumers. Acta Oeconomica Universitatis Selye, 7(2), 162-174 (2018)

2. E. Kicova, M. Nadanyiova, Brand as a Tool of Company's Strategic Marketing in Practice Conference. Proceeding of 7th ESE International Conference on Sports, Health and Management. Lecture Notes in Management Science, 73, pp. 29-34 (2017)

3. M. Palatkova, The Opportunities to Assess the Performance of Destination Marketing Management. 12th International Conference on Hradec Economic Days (HED 2014): Economic Development and Management of Regions Location, pp. 362-371 (2014)

4. M. Hesková, P. Štarchoň, Marketingová komunikace a moderní trendy v marketing [Marketing communication and modern trends in marketing]. Prague: Oeconomica (2009)

5. L. Mura, B. Gontkovicova, E. Dulova Spisakova, Z. Hajduova, Position of Employee Benefits in Remuneration Structure. Transformations in Business \& Economics, 2(47), 156-173 (2019)

6. R. Benda-Prokeinová, K. Dobeš, L. Mura, J. Buleca, Engel's Approach as a tool for estimating consumer behaviour. E \& M Ekonomie a Management, 20(2), 15-29 (2017)

7. M. Karlíček, P. Král, Marketingová komunikace: jak komunikovat na našem trhu [Marketing communication: how to communicate in our market]. Prague: Grada (2011)

8. A. Krizanova, L. Gajanova, M. Nadanyiova, Design of a CRM Level and Performance Measurement Model. Sustainability, 10(7) (2018)

9. L. Vilcekova, P. Starchon, Consumer Perception of Selected Brands Explored through Archetypes. Proceeding of the 4th International Conference on Education and Social Sciences (INTCESS) Istanbul, pp. 819-823 (2017) 
10. J. Brych, Věrnostní program neprodává, ale buduje [The loyalty program does not sell but builds]. Marketing a Media [Marketing and Media] [online], Available at: http://mam.ihned.cz/c1-63329390-vernostni-program-neprodava-ale-buduje (2015)

11. M. Zamazalová, Marketing obchodni firmy [Business company marketing]. Prague: Grada (2009)

12. D. Waari, R. Bonuke, D. Kosgei, Loyalty programs benefits and customer loyalty: The mediating role of customer satisfaction. International Journal of Commerce and Management, 6(4), 726-737 (2018)

13. G.J. Tellis, Reklama a podpora prodeje [Advertising and sales promotion]. Prague: Grada (2016)

14. F. Reichheld, T. Teal, The loyalty effect: the hidden force behind growth, profits, and lasting value. Harvard Business School Press (2001)

15. E. Smolkova, P. Starchon, D. Weberova, Country-of-Origin Brands from the Point of View of the Slovak and Czech Consumers. Proceeding of conference Innovation Management and Education Excellence Vision 2020. From Regional Development Sustianablility to Global Economic Growth, pp. 2119-2130 (2016)

16. T. Fu, C. Li, L. Guo, Y. Wang, How we view competitions between the converging Internet social platforms: Does higher user number mean the final victory. International Journal of Modern Physics C, 26(8) (2015)

17. V. Nývlt, The role of managing knowledge and information in BIM implementation processes in the Czech Republic. 9th International Scientific Conference on Building Defects (Building Defects), 146 (2018)

18. J. Lojda, K. Ventrubová, The Grant Policy of the Forestry Sector in the Czech Republic After 2013. Reports of Forestry Research-Zpravy Lesnickeho Vyzkumu, 60(1), 64-72 (2015)

19. V. Mulačová, P. Mulač et al., Obchodni podnikání ve 21. Století [Business in the $21^{\text {st }}$ century]. Prague: GRADA Publishing (2013)

20. Y. Liu, The long-term impact of loyalty programs on consumer purchase behavior and loyalty. Journal of Marketing, 71(4), 19-35 (2007)

21. P. Seemann, V. Farkasova, Coaching as a tool for Improving the Quality of Managerial Work. Proceeding of Conference: 15th International Scientific Conference on Globalization and its Socio-Economic Consequences, pp. 661-669 (2015)

22. R. Kampf, S. Lorincova, M. Hitka, O. Stopka, Generational Differences in the Perception of Corporate Culture in European Transport Enterprises. Sustainability, 9(9) (2017)

23. I. Kmecová, Analysis of the Efficiency of the Educational Processes of the Subjects Business Management, Human Resource Management, and Mathematics, and their Comparison. 12th International Technology, Education and Development Conference (INTED), pp. 1781-1788 (2018)

24. A. Kucharcikova, M. Miciak, Human Capital Management in Transport Enterprises with the Acceptance of Sustainable Development. Sustainability, 10(7) (2018)

25. S. Lorincova, M. Hitka, Z. Balazova, Corporate Culture in Slovak Enterprises as a factor of HRM Quality - Case Study. International Journal for Quality Research, 10(4), 719732 (2016)

26. V. Cempirek, I. Drahotsky, P. Vrbova, The Concept of Prices from Antiquity to today in Comparison with Selected Current International trends. Proceeding of the Conference: 14th International Scientific Conference of Doctoral Students and Young 
Scientists on Economic, Political and Legal Issues of International Relations, pp. 68-75 (2015)

27. G. Fedorko, S. Honus, S. Badiarova, Analysis of the Utilization of Machinery in the Production Process Using Computer Simulation. MATEC Web of Conferences: 18th International Scientific Conference on LOGI, 134 (2017)

28. M. Dobrodolac, L. Svadlenka, M. Cubranic-Dobrodolac, et al., A model for the comparison of business units. Personel Review, 47(1), 150-165 (2018)

29. Z. Musová, Responsible behavior of businesses and its impact on consumer behavior. Acta Oeconomica Universitatis Selye, 4(2), 138-147 (2015)

30. M. Gogolová, The doorstep sales and the selling events in Slovakia. Acta Oeconomica Universitatis Selye, 3(2), 33-39 (2014) 